The situation in which these requests have been arising is analysed and related to the presuppositions which lay behind the ideas expressed in the requests.

There is no evidence in this country that families are irresponsible, but plenty to indicate that shortage of hospital services for the elderly in the area under review are artificially produced, there being, overall, on accepted criteria, a great excess of hospital beds in relation to the resident population.

The main cause for this was the obsession with medical science and technology giving a producer-orientated service, the source and generator of runaway medicine.

The old historical accidents of " acute" and "chronic," given indirect statutory sanction in the past, have been perpetuated despite the disappearance 20 years ago of the legal obligations which determined their perpetuation.

The alternative to the scientific approach is the rejection and conspiracy of residual custody, with their assault on human dignity, for those for whom or to whom science could do nothing. This traditional approach cannot be contained in an affluent society with full employment and a decreasing number of single women.

The answers lie in the historian's method of approach, which is more inclusive than the scientific, the concept of breakdown in practical and effective living, and the place a hospital has in providing sufficient support for the maximum of personal independence.

Disability is not the same as disease and explanation is not prediction reversed.
I wish to thank those who work with me: Mrs. J. M. Taylor, A.I.M.S.W., who went through this manuscript and made many helpful suggestions, and Dr. W. B. Harman, Dr. Monnica Stewart, Dr. Betty Jacobs, Miss J. F. Kenyon Rogers, A.I.M.S.W., Miss B. M. Fischel, A.I.M.S.W., Mrs. M. Hawker, M.C.S.P., Miss D. Thomas, M.A.O.T., and Miss P. M. Leche, L.C.S.T.

\section{REFERENCES}

Carr, E. H. (1964). What is History ? London.

Collingwood, R. G. (1946). The Idea of History. London.

Dray, W. (1957). Laws and Explanation in History. London.

Galbraith, J. K. (1966). The Reith Lectures No. 6, Listener, 74, 915.

Gallie, W. B. (1964). Philosophy and the Historical Understanding.

London.

Hart, H. L. A. (1961). The Concept of Law. London.
and Honore, A. M. (1959). Causation in the Law (to page 140). London.

Hunter, T. D. (1967). New Society, 9, 356.

Laslett, P. (1965). The World We Have Lost. London.

Lowther, C. P., and Williamson, J. (1966). Lancet, 2, 1459.

Louch, A. R. (1966). Explanation and Human Action. Oxford.

Ministry of Health (1966). The Hospital Building Programme. H.M.S.O., London.

Norton, D. (1966). Personal communications.

(1967). Hospital of the Long Stay Patient. Oxford.

Society for Promoting Christian Knowledge (1966). Putting Asunder. $A$ Divorce Law for Contemporary Society. London. (For compari-

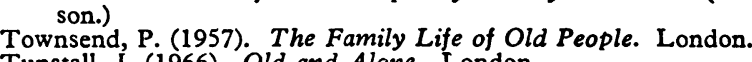

Tunstall, J. (1966). Old and Alone. London.

Willmott, P., and Young, M. (1960). Family and Class in a London Suburb. London.

Winch, F. (1958). The Idea of a Social Science. London.

Young, M., and Willmott, P. (1957). Family and Kinship in Eas. London. London.

\title{
Mitral Valvotomy in Elderly Patients
}

\author{
H. E. KULBERTUS*† ; A. R. KIRK*
}

Brit. med. F., 1968, 1, 274-277

Most patients with untreated mitral stenosis die befure the age of 50 (DeGraff and Lingg, 1935 : Olesen, 1955 ; Wood, 1956). Those who survive are liable to have atrial fibrillation, rigid and calcified valves, cardiac enlargement, and chronic heart failure over and above the other conditions to which elderly people are prone (hypertension, atherosclerosis, diabetes, chronic airways obstruction). On account of these factors there are differences of opinion among cardiologists on the advisability of mitral valvotomy in those aged 50 or over, where the operative risks and the proportion of poor results have of ten been reported to be higher (Goodwin et al., 1955 ; Ellis et al., 1959 ; Lowther and Turner, 1962 ; Reid et al., 1966).

Surgical experience of closed mitral valvotomy at the Royal Postgraduate Medical School now includes 75 patients aged 50 or over. The results of surgery are examined critically in the light of preoperative findings, and the various potentially adverse factors are analysed for their effect on operative mortality and long-term results.

\section{Patients}

The present study is concerned with 77 mitral valvotomies carried out on 75 patients aged 50 years or over. The operations were performed by Mr. W. P. Cleland, Professor H. H. Bentall, and their surgical colleagues. The period under review extends from 1954 to July 1966. Of the 75 patients 65 were female. Their ages ranged from 50 to 67 years: 38 were 50

\footnotetext{
- Department of Medicine (Clinical Cardiology), Royal Postgraduate Medical School of London and Hammersmith Hospital, London W.12. † Aspirant du Fonds National Belge de la Recherche Scientifique.
}

to 54 years, 27 were 55 to 59 , and 12 were 60 or over at the time of each valvotomy. A history of rheumatic fever was obtained in $38(51 \%)$. Eight patients had had a previous valvotomy ; for two of them the current operation was the third.

\section{Preoperative and Operative Findings}

Symptoms.-Dyspnoea was present in all but one patient. From careful consideration of the history and observation of the patients' effort tolerance while in hospital the degree of dyspnoea was estimated as grade 1 in 2 cases, grade $2 \mathrm{a}$ in 20 , grade $2 \mathrm{~b}$ in 45 , and grade $3-4$ in 7 (using the criteria of Goodwin et al., 1955). Preoperative systemic embolism occurred in 20 patients $(27 \%)$; repetitively in eight. The commonest sites were the femoral (15 episodes) and cerebral arteries (14 episodes). Two patients had a history of coronary embolism or thrombosis. Fifteen patients $(20 \%)$ suffered from chronic obstructive airways disease, which was severe in nine. One had asbestosis, another bronchiectasis. Pain suggestive of angina of effort was a feature in $12(16 \%)$. One had StokesAdams attacks. Twelve had had previous episodes of cardiac failure. A history of haemoptysis was obtained in five.

Physical Findings.-The incidence of atrial fibrillation was extremely high (56 patients; $75 \%$ ) and increased with age, as shown in Table I (Obeyesekere et al., 1965; Reid et al., 1966). Twenty-seven patients (36\%) had clinical evidence of associated valve disease. In 17 cases some degree of aortic valve disease was diagnosed; it was regarded as mild in 10 instances (six with aortic regurgitation, three with aortic stenosis, and one with mixed aortic valve disease) and as 
moderate in seven (six with aortic regurgitation and one with aortic stenosis). Three patients had severe and one patient had mild tricuspid stenosis. Functional tricuspid incompetence was noted in seven cases and functional pulmonary incompetence in three. Systemic hypertension with a diastolic pressure over $100 \mathrm{~mm}$. Hg was encountered in $10(13 \%)$. Diabetes mellitus was diagnosed in four.

\section{TABLE I.-Incidence of Atrial Fibrillation in Each Age Group}

\begin{tabular}{ll|l|l|l|l} 
Age group (years) &.. & $50-55$ & $55-60$ & $>60$ \\
Percentage of patients in atrial fibrillation & $\ldots$ & 72 & 76 & 82
\end{tabular}

Radiological Findings.-Postero-anterior and lateral radiographs were taken with barium swallow to outline the left atrium. In all cases tomograms were examined for atrial and valvar calcification. The left atrial enlargement was described as slight in $\mathbf{3 5}$ cases, moderate in $\mathbf{2 8}$, and marked or aneurysmal in 12. Cardiac enlargement (C.T. ratio $\geqslant 0.6$ ) was present in $39(52 \%)$. Pulmonary arterial changes were carefully examined on the plain films, and could be assessed satisfactorily in 66 patients. According to the criteria of Davies et al. (1953) pulmonary hypertension was mild or absent in 28 patients, moderate in 31 , and severe in 7 . The mitral valve was slightly calcified in 18 cases (24\%) and heavily calcified in $19(25 \%)$. Calcification of the atrial wall was present in four patients.

Surgical Assessment.-Mitral valvotomy was performed by finger-split in 17 cases and transventricular dilator in 59. In one case the procedure was limited to exploration of the valve. The following points were noted: (a) valvar calcification (present in $49 \%$ of the cases) ; (b) mobility of the valve (rigid in $22 \%$, poor in $19 \%$, fair in $19 \%$, and good in $40 \%$ ); (c) size of the mitral orifice-less than $1 \mathrm{~cm}$. (25\%), 1-1.5 cm. ( $40 \%), 1.5-2 \mathrm{~cm}$. (22\%), more than $2 \mathrm{~cm}$. (13\%) as estimated by the surgeon's finger; $(d)$ presence of mitral regurgitation before the split, which was graded 1 for a trivial puff $(18 \%)$, 2 for a moderate stream (2.6\%), and 3 for a considerable regurgitant stream with thrill $(18 \%)$; and $(e)$ split obtained graded as "good" (final orifice greater than $3 \mathrm{~cm} ., 77 \%$ ), "fair" (2.5-3 cm., 6.5\%), or "poor" (less than $2 \mathrm{~cm}$., 10\%). The remaining $6.5 \%$ were not graded for size of the final orifice.

\section{Results of Mitral Valvotomy}

\section{Operative or Early Deaths}

Five patients $(6.7 \%)$ died at operation or within five days. This mortality rate is not significantly different from that in the series of 434 patients of all ages operated on at Hammet: smith Hospital since $1954(5.9 \%)$. It is definitely lower than the mortality reported in the series of elderly patients published up to now (Lowther and Turner, 1962 ; Reid et al., 1966), Four other patients died within a year of operation. Pre operative and operative factors in these patients are analysed in Table II.

\section{Symptomatic Results}

The survivors have been followed up for periods ranging from a few weeks to 12 years. Those on whom valvotomy was performed less than six months before this analysis was made have been excluded, the duration of follow-up being too short. Postoperative results have been divided into three categories: "good," "fair," and "poor." Good implies marked improvement in effort tolerance, with ability to carry out normal activities. Fair implies worth-while improvement but still with restriction in activity. A poor result implies little or no improvement, or actual deterioration after surgery. The results are set out in Table III.

TABLE III.-Symptomatic Results of Mitral Valvotomy in 75 Elderly Patients

\begin{tabular}{|c|c|c|c|c|c|c|c|c|c|}
\hline \multirow{3}{*}{$\begin{array}{c}\text { Duration } \\
\text { of } \\
\text { Follow-up }\end{array}$} & \multirow{3}{*}{$\begin{array}{l}\text { No. of } \\
\text { Patients }\end{array}$} & \multicolumn{8}{|c|}{ Results } \\
\hline & & \multicolumn{2}{|c|}{ Good } & \multicolumn{2}{|c|}{ Fair. } & \multicolumn{2}{|c|}{ Poor } & \multicolumn{2}{|c|}{ Dead } \\
\hline & & No. & $\%$ & No. & $\%$ & No. & $\%$ & No. & $\%$ \\
\hline 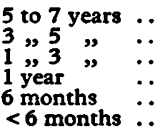 & $\begin{array}{l}12 \\
22 \\
38 \\
48 \\
55 \\
75\end{array}$ & $\begin{array}{r}5 \\
9 \\
16 \\
19 \\
26\end{array}$ & $\begin{array}{l}41 \cdot 5 \\
41 \\
42 \\
39 \cdot 5 \\
47 \cdot 25\end{array}$ & $\begin{array}{r}4 \\
4 \\
10 \\
15 \\
23\end{array}$ & $\begin{array}{l}33 \cdot 5 \\
18 \cdot 5 \\
26 \\
31 \cdot 5 \\
42\end{array}$ & $\begin{array}{r}2 \\
6 \\
9 \\
12 \\
4\end{array}$ & $\begin{array}{l}16 \cdot 5 \\
27 \\
24 \\
25 \\
7 \cdot 25\end{array}$ & $\begin{array}{l}1 \\
3 \\
3 \\
2 \\
2 \\
5(a\end{array}$ & $\begin{array}{r}8.5 \\
13.5 \\
8 \\
4.5 \\
3.5 \\
\text { top.) }\end{array}$ \\
\hline
\end{tabular}

The auscultatory signs of mitral stenosis, the clinical and radiological signs of pulmonary hypertension, the electrocardiographic evidence of right ventricular hypertension, and the cardiothoracic ratio failed to improve in $71 \%$ of the patients. In the cases where one or several of the objective signs decreased after surgery, the subjective results were always good or at least fair.

\section{Postoperative Complications}

Atrial Fibrillation.-Of 17 patients who were in sinus rhythm before operation $13(76 \%)$ developed atrial fibrillation in the immediate postoperative period. None of them reverted to sinus rhythm spontaneously, but there were successfully

TABLE II.-Preoperative and Operative Findings in Nine Women who Died at Operation or Within a Year after Mitral Valvotomy

\begin{tabular}{|c|c|c|c|c|c|c|c|c|c|c|c|c|c|}
\hline Age & $\begin{array}{l}\text { Dysponoea } \\
\text { Grade }\end{array}$ & $\begin{array}{l}\text { Cardiac } \\
\text { Failure }\end{array}$ & T.I. & A.P. & P.H.T. & $\begin{array}{c}\text { Cardiac } \\
\text { Enlarge- } \\
\text { ment }\end{array}$ & $\begin{array}{l}\text { Diam. } \\
\text { Valve } \\
\text { cm. } \\
\text { Ca. }\end{array}$ & $\begin{array}{l}\text { M.I. } \\
\text { Before } \\
\text { Op. }\end{array}$ & $\begin{array}{l}\text { Postop. } \\
\text { M.I. }\end{array}$ & Split & Survival & $\begin{array}{l}\text { Cause of } \\
\text { Death }\end{array}$ & Comments \\
\hline 50 & $3-4$ & + & + & + & II & + & $\begin{array}{l}1.7 \\
+ \\
0.8\end{array}$ & $\mathbf{0}$ & $\mathbf{0}$ & Poor & $\begin{array}{l}\text { Death on } \\
\text { table } \\
n, "\end{array}$ & $\begin{array}{l}\begin{array}{l}\text { Ventricular } \\
\text { fibrillation }\end{array} \\
\text { Haemorrhage }\end{array}$ & $\begin{array}{l}\text { Severe aortic stenosis. In } \\
\text { Cardiac failure before op. } \\
\text { Rheumatism in activity } \\
\text { Tear in auricular wall }\end{array}$ \\
\hline 67 & 2b & $\mathbf{0}$ & + & + & $\mathbf{I}$ & + & $\stackrel{0}{1}$ & $\mathbf{0}$ & $\mathbf{0}$ & Good & 24 hours & $\begin{array}{l}\text { Haemorrhage. } \\
\text { Hypotension. } \\
\text { Pumonary }\end{array}$ & $\begin{array}{l}\text { Strokes } 5 \text { years before. Haemor- } \\
\text { rhage from chest wall }\end{array}$ \\
\hline 54 & $\mathbf{2 b}$ & + & $\mathbf{0}$ & + & II & + & $1 \cdot 5$ & ++ & ++ & - & $\begin{array}{l}\text { Death on } \\
\text { table }\end{array}$ & $\begin{array}{l}\text { Ventricular } \\
\text { fibrillation }\end{array}$ & Diabetes. Second valvotomy \\
\hline 66 & $2 \mathbf{b}$ & + & $\mathbf{0}$ & + & $\mathbf{0}$ & + & & 0 & $\mathbf{0}$ & Good & 120 hours & Cerebrovascular & Diabetes. Widespread \\
\hline 53 & $\mathbf{2 b}$ & $\mathbf{0}$ & 0 & + & r & + & 1.5 & + & + & " & 3 months & Cerebral embolus & \\
\hline 59 & $2 b$ & $\mathbf{0}$ & 0 & + & $?$ & + & $t_{+}^{+2}$ & + & ++ & Fair & 53 & $\begin{array}{l}\text { Multiple emboli } \\
\text { (brain, leg, heart, }\end{array}$ & $\begin{array}{l}\text { Severe bronchitis. Paroxysmal } \\
\text { nocturnal dyspnoea }\end{array}$ \\
\hline 58 & $\mathbf{2 b}$ & + & $\mathbf{0}$ & + & $\mathbf{I}$ & + & $\stackrel{2}{+}+$ & $\mathbf{0}$ & + & Good & $8 n^{\circ}$ & $\begin{array}{l}\text { Deep vein throm- } \\
\text { bosis. Pulmonary }\end{array}$ & $\begin{array}{l}\text { Severe bronchitis. In cardiae } \\
\text { failure at operation }\end{array}$ \\
\hline 51 & $2 \mathbf{b}$ & + & 0 & + & I & + & $1 \cdot 5$ & $\mathbf{0}$ & ++ & $"$ & 8 " & Cardiac failure & $\begin{array}{l}\text { In cardiac failure at operation, } \\
\text { Severe M.I. produced by } \\
\text { surgery }\end{array}$ \\
\hline
\end{tabular}


defibrillated by direct-current conversion and were still in sinus rhythm. None of the 58 patients with established atrial fibrillation before operation reverted spontaneously afterwards. In all of them the arrhythmia had been present for a long time and conversion was not attempted.

Mitral Regurgitation.-Twenty-five of $56(45 \%)$ patients who did not present with mitral incompetence before surgery were found to have some degree of mitral incompetence after operation. The regurgitation was trivial in 10 cases, significant in 11, and severe in 4. Moreover, significant mitral incompetence was produced in five patients in whom mild regurgitation had already been present before operation.

Systemic Embolism.-In patients in whom clot was found in the atrium the three main branches of the aorta were controlled with tape during valvotomy. Moreover, since 1958 all the patients submitted to mitral valvotomy received prophylactic treatment with anticoagulants for three weeks preceding surgery and most of them for six weeks or longer (Smith et al., 1965). Because of these precautions a systemic (saddle) embolus occurred in only one patient within a week of operation. However, embolic complications arose later in six patients. One had a femoral embolus seven months after valvotomy. Four had clinical evidence of cerebral embolism three months, six months, four years, and five years after operation. One other patient had femoral and cerebral emboli four months after surgery, confirmed shortly afterwards when she died from coronary and pulmonary infarcts.

Pulmonary Emboli.-Pulmonary embolism occurred in four patients 24 hours, six months, eight months, and five years respectively after operation. Two patients died from this complication.

Tricuspid Valve Disease.-Tricuspid incompetence, which was present in seven patients before operation, disappeared in five and worsened in two. Five developed fixed tricuspid incompetence after mitral valvotomy (Mounsey, 1959). One patient developed clinical signs of tricuspid stenosis.

Infections.-One patient developed an empyema soon after surgery. Another required prostatectomy four weeks after mitral valvotomy. This additional surgical procedure was followed by subacute bacterial endocarditis. A third patient developed subacute bacterial endocarditis one year after operation. These infections did not prevent a good result later on.

Restenosis.-Restenosis of the mitral valve occurred in nine patients after periods ranging from one to six years-in eight of them after a good valvotomy. At operation the valve had been described as fairly mobile in four and as sclerotic and calcific in five.

\section{Relation between Potentially Adverse Factors and Post- operative Progress in 45 Patients Followed Up During Three Years After Surgery}

Table IV shows the effect on the operative results of 12 factors. As diabetes and tricuspid stenosis were rare features in this series they are not included in Table IV but are discussed separately.

From these figures it appears that the proportion of patients who derived no benefit or actually died within three years of operation is significantly higher in those with calcification of the mitral valve, severe preoperative mitral regurgitation, previous episodes of cardiac failure, and severe chronic airways disease. This proportion is also apparently higher in the cases with cardiac enlargement, but the difference is not statistically significant.

These figures deserve some comment. The significance of each factor is valid only if the two groups of patients with worth-while improvement and poor results do not differ in other respects. Most of these adverse factors tend to appear in association, and the figures of Table $\mathrm{V}$ do not necessarily reflect the influence of each of them separately. Nevertheless, if we try to analyse the significance of each condition by extracting from the series a group which differs only in respect of this feature, the total numbers become too small for conclusions to be drawn. TABLE IV.-Relation of Preoperative Findings to the Symplomatic
Results in 45 Patients During the First Three Years After Valvotomy

\begin{tabular}{|c|c|c|c|c|}
\hline \multirow{2}{*}{$\begin{array}{l}\text { Preoperative } \\
\text { Findings }\end{array}$} & \multicolumn{2}{|c|}{$\begin{array}{c}\text { Results } 3 \text { Years after } \\
\text { Valvotomy (45 Patients) }\end{array}$} & \multirow[b]{2}{*}{$x^{2}$} & \multirow[b]{2}{*}{ Significance } \\
\hline & $\begin{array}{c}\text { Good and } \\
\text { Fair Results } \\
\text { (25 Patients) } \\
\end{array}$ & $\begin{array}{l}\text { Poor Results } \\
\text { or Deaths } \\
\text { (20 Patients) }\end{array}$ & & \\
\hline $\begin{array}{l}\text { Age (mean) } \\
\text { Atrial fibrillation } \\
\text { Calcification of mitral valve } \\
\text { Mitral incompetence: }\end{array}$ & $\begin{array}{l}54 \cdot 5 \\
17 \\
7\end{array}$ & $\begin{array}{l}55 \cdot 5 \\
17 \\
12\end{array}$ & $\overline{1 \cdot 79}$ & $\begin{aligned} & \stackrel{0}{0} \\
+P & <0.05\end{aligned}$ \\
\hline $\begin{array}{l}\text { Significant } \\
\text { Severe } \ddot{0} \\
\text { Previous episodes of cardiac }\end{array}$ & $\begin{array}{l}3 \\
\mathbf{0}\end{array}$ & $\begin{array}{l}6 \\
5\end{array}$ & $\begin{array}{l}2.25 \\
7.03\end{array}$ & $+P \stackrel{0}{<0.01}$ \\
\hline $\begin{array}{l}\text { Cailure } \\
\text { Cardiac enlargement } \\
\text { Tricuspid incompetence } \\
\text { Previous valvotomy } \\
\text { Severe chronic obstructive }\end{array}$ & $\begin{array}{r}0 \\
11 \\
6 \\
2\end{array}$ & $\begin{array}{r}9 \\
10 \\
5 \\
3\end{array}$ & $\begin{array}{c}13.4 \\
3.05 \\
0.035 \\
0.415\end{array}$ & $\begin{array}{c}+P<0.01 \\
0 \\
0 \\
0\end{array}$ \\
\hline 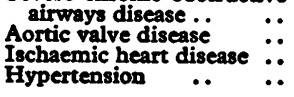 & $\begin{array}{l}0 \\
7 \\
7 \\
4\end{array}$ & $\begin{array}{l}7 \\
6 \\
0 \\
5\end{array}$ & $\begin{array}{l}10.4 \\
0.19 \\
6.75 \\
0.565\end{array}$ & $\begin{array}{c}+P<0.01 \\
0 \\
+\left(\begin{array}{c}\text { reversed }) \\
0\end{array}\right.\end{array}$ \\
\hline
\end{tabular}

TABLB V.-Incidence of Adverse Factors in Elderly Patients and in Series of Patients of All Ages

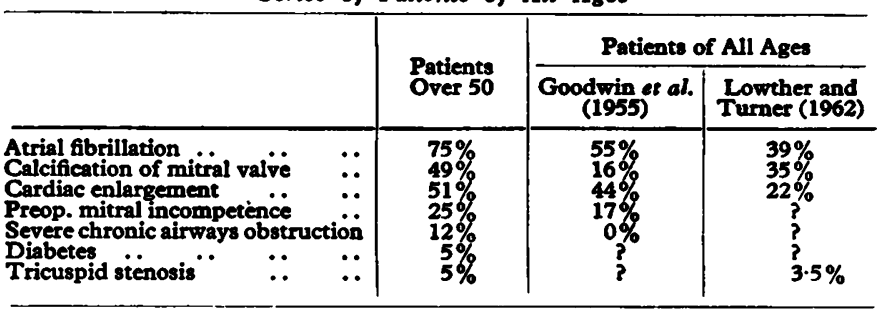

From this analysis and by contrast to what is commonly found in series of patients of all ages (Lowther and Turner, 1962) it did not appear that the proportion of poor results or deaths has been greater in the patients with atrial fibrillation. It is important to remember that in this age group most of the patients with mitral stenosis have atrial fibrillation, and this feature is clearly related to age (Obeyesekere et al., 1965).

It would also appear from these figures that systemic hypertension does not influence the operative results, and that even the proportion of patients who maintain a good result is higher in those with ischaemic heart disease. This is misleading, since in fact patients presenting with either of these two conditions have been thought to have a bad surgical prognosis. Therefore the selection in these cases has been very strict, which may explain the surprisingly good results. Most patients with angina had a very small mitral orifice and severe pulmonary hypertension. Their pain was possibly related to low cardiac output. In most of the cases angina disappeared postoperatively.

Diabetes and tricuspid stenosis have not been included in Table IV because their numbers are too small to allow any conclusion to be drawn. Of the four diabetic patients, two died at operation (one from cardiac arrest and one from cerebrovascular accident) and two had poor results. Of the four patients with tricuspid stenosis, three derived considerable benefit from mitral valvotomy-an improvement maintained for more than three years-and the other went into cardiac failure soon after operation and died five years later.

From these figur:s we conclude that the following features must be regarded as adverse factors in mitral valvotomy in the elderly: firstly, calcification of the mitral valve (Kitchin and Turner, 1967); secondly, severe preoperative mitral regurgitation ; thirdly, previous episodes of cardiac failure ; fourthly, severe chronic obstructive airways disease ; and, fifthly, possibly cardiac enlargement, diabetes, and tricuspid stenosis. 
The influence of the adverse factors is shown in Figs. 1 and 2. The series has been divided into two groups: the first consists of patients without adverse factors, and the second of patients with at least one adverse factor. The survival curves (Fig. 1) constructed from the life-table method recommended by Merrell and Shulman (1955) show that the mortality rate is significantly higher in the group with adverse factors. The symptomatic results three years after operation are also obviously more encouraging in the uncomplicated group (Fig. 2).
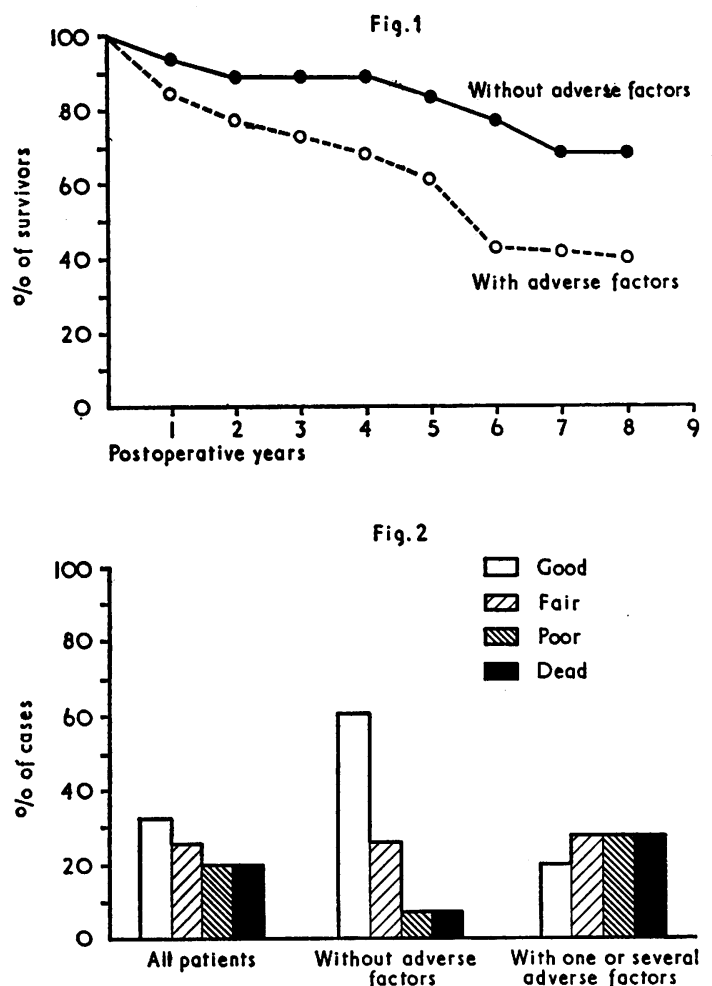

Fig. 1.- Influence of adverse factors on the survival curves after mitral valvotomy in patients aged 50 years or over. FIG. 2. - Influence of adverse factors on the symptomatic results three years after mitral valvotomy in 45 patients aged 50 years or over.

\section{Discussion and Conclusion}

Most of the follow-up studies hitherto published of patients submitted to mitral valvotomy show that the mortality rate as well as the incidence of poor results is higher in the elderly patient.

Advancing age must undoubtedly worsen the outlook because of the increasing incidence of adverse factors: calcification of mitral valve, severe preoperative mitral incompetence, previous episodes of cardiac failure, severe chronic obstructive airways disease, and, possibly, cardiac enlargement, diabetes, and tricuspid valve disease. When selecting patients for surgery special attention must be paid to these factors as well as to hypertension and coronary insufficiency. Nevertheless, the relatively poor prognosis in elderly patients submitted to mitral valvotomy does not appear to be related to age itself. Fig. 2 clearly shows that, provided no adverse factor is associated with mitral stenosis, the outlook is definitely better, and the operative results are not in these circumstances significantly different from those published for series of younger patients (Lowther and Turner, 1962). Thus no patient should be denied the opportunity of surgical relief on account of age alone.

\section{Summary}

The preoperative and operative findings in 75 patients aged 50 and over submitted to mitral valvotomy are presented, and the operative results and postoperative progress are described. Analysis of the influence of preoperative and operative findings on progress after surgery shows that calcification of the mitral valve, severe preoperative mitral insufficiency, previous episodes of cardiac failure, severe chronic obstructive airways disease, and, possibly, cardiac enlargement, diabetes, and tricuspid stenosis must be regarded as adverse factors. Their high incidence in the over-50 group seems to be responsible for the usual poor prognosis of mitral valvotomy in this age group. Age itself must not be regarded as a contraindication, since when the conditions are good mitral valvotomy is both worth while and rewarding in the elderly patient.

We wish to thank Professor J. F. Goodwin for his support and valuable suggestions and Dr. C. M. Oakley for her useful constructive criticism. We are grateful to Mr. W. P. Cleland and Professor H. H. Bentall for their collaboration.

\section{REFERENCES}

Davies, L. G., Goodwin, J. F., Steiner, R. E., and Van Leuven, B. D. (1953). Brit. Heart F., 15, 393.

DeGraff, A. C., and Lingg, C. (1935). Amer. Heart f., 10, 630.

Ellis, L. B., Harken, D. E., and Black, H. (1959). Circulation, 19, 803.

Goodwin, J. F., Hunter, J. D., Cleland, W. P., Davies, L. G., and Steiner, R. E. (1955). Brit. med. F., 2, 573.

Kitchin, A., and Turner, R. (1967). Brit. Heart f., 29, 137.

Lowther, C. P., and Turner, R. W. D. (1962). Brit. med. F., 1, 1027.

Merrell, M., and Shulman, L. E. (1955). 7. chron. Dis., 1, 12

Mounsey, P. (1959). Brit. Heart f., 21, 123.

Obeyesekere, H. I., Dulake, M., Demerdash, H., and Hollister, R. (1965). Brit. med. ₹., 2, 441.

Olesen, K. H. (1955). Mitral Stenosis: A Follow-up of 351 Patients. Copenhagen.

Reid, J. M., Barclay, R. S., Stevenson, J. G., Welsh, T. M., and McSwan, N. (1966). Brit. med. ₹., 2, 1044.

Smith, B., Umapathy, A., Bentall, H. H., and Cleland, W. P. (1965). Brit. Heart $7 ., 27,618$.

Wood, P. H. (1956). Diseases of the Heart and Circulation, 2nd ed. London. 